\title{
KAJIAN TEKNIK OPERASIONAL PENGEMBANGAN TPST EDELWEISS SEBAGAI UPAYA PENGELOLAAN SAMPAH SKALA KAWASAN
}

\author{
Fitra Muthia Khanza $^{11}$, Laili Fitria $^{11}$, Ulli Kadaria ${ }^{1)}$ \\ ${ }^{1)}$ Program Studi Teknik Lingkungan Jurusan Teknik Sipil Fakultas Teknik Universitas Tanjungpura, Pontianak \\ Email : fitramuthiakhanza@gmail.com
}

\begin{abstract}
ABSTRAK
TPST adalah tempat dilakukannya kegiatan pengumpulan, pemilahan, penggunaan ulang, pendaur ulang, pengolahan dan pemrosesan akhir sampah. TPST merupakan bagian dari pengelolaan sampah yang dapat mereduksi sampah yang masuk ke TPA. Di Kota Pontianak, sudah terdapat TPST Edelweiss yang berdiri sejak tahun 2015. Namun hingga tahun 2017, TPST Edelweiss hanya mengelola sampah Pasar sehingga diperlukan pengembangan luas TPST yang mengelola sampah skala kawasan. Tujuan penelitian ini, menganalisis timbulan sampah yang terdapat di Pasar Pagi dan kondisi eksisting TPST Edelweiss dari segi aspek teknik operasional, menganalisis pengembangan pengelolaan sampah di TPST Edelweiss skala pasar menjadi skala kawasan. Perhitungan jumlah sampel sampah menggunakan metode proportionate statified random sampling. Teknik pengambilan dan pengukuran sampel sampah mengacu pada SNI 193694-1994 dilakukan selama 8 hari. Timbulan sampah organik Pasar Pagi 0,386 $\mathrm{m}^{3} / \mathrm{unit} /$ hari dan anorganik 0,002 $\mathrm{m}^{3} /$ unit/hari. TPST Edelweiss memiliki area penumpukan dan pemilahan $12 \mathrm{~m}^{2}$, pencacahan dan penimbangan $12 \mathrm{~m}^{2}, 21$ bak pengomposan, pengayakan dan pengemasan kompos $9 \mathrm{~m}^{2}$, dan 1 reaktor biogas fixed dome $10 \mathrm{~m}^{3}$. Pengembangan TPST Edelweiss menjadi skala kawasan membutuhkan area penumpukan $100 \mathrm{~m}^{2}$, area pemilahan $157,44 \mathrm{~m}^{2}$ dengan conveyor belt, area pencacahan $30,176 \mathrm{~m}^{2}$, area pengomposan metode open windrow composting dengan luas area $3421,83 \mathrm{~m}^{2}$, area pengayakan dan pengemasan kompos dengan luas area $16,5 \mathrm{~m}^{2}$, area anorganik dan B3 membutuhkan luas $94,64 \mathrm{~m}^{2}$, reaktor biogas tipe fixed dome $10 \mathrm{~m}^{3}$, gudang $80 \mathrm{~m}^{2}$, lahan parkir $34,44 \mathrm{~m}^{2}$, rumah jaga $24 \mathrm{~m}^{2}$. Luas yang dibutuhkan untuk mengelola sampah dalam skala kawasan adalah 4458,143 $\mathrm{m}^{2}$.
\end{abstract}

Kata Kunci: Pengelolaan Sampah, Pengembangan, TPST

\begin{abstract}
TPST is a place for activities such as collecting, distinguishing, reusing, recycling and processing as the final phase of waste management. TPST is a phase of waste management that possible to reduce the waste that goes to waste disposal. In Pontianak, TPST Edelweiss had established since 2015. Whereas until 2017 TPST Edelweiss only worked with the market's waste, which is necessary to be developed for waste management in district scale. The purpose of this research are analyzing the waste pile at the Pasar Pagi and condition of how the existing of TPST Edelweiss can be turned from market' scale into district scale, according to several aspects such as operational technique, analysis on the development of waste management in TPST Edelweiss. The calculation of the amount of waste sampling by using proportionate statified random sampling method. The measurement technique of the waste sampling refers to SNI 19-3694-1994 that have been doing in eight days. Organics waste pile at the Pasar Pagi $45,174 \mathrm{~m}^{3} /$ days while anorganics $0,242 \mathrm{~m}^{3}$ /days. TPST Edelweiss has $12 \mathrm{~m}^{2}$ area for collecting and distinguishing the waste, devastating and scaling area $12 \mathrm{~m}^{2}, 21$ compost bin, shifting and packaging compost $9 \mathrm{~m}^{2}$, and 1 biogas fixed dome reactor $10 \mathrm{~m}^{3}$. The development of TPST Edelweiss into district scale needs $100 \mathrm{~m}^{2}$ for collecting area. $157.44 \mathrm{~m}^{2}$ for distinguishing area with conveyor belt. $30.176 \mathrm{~m}^{2}$ for devastating area. Compost area with open windrow composting method within $3421.83 \mathrm{~m}^{2}$. $16.5 \mathrm{~m}^{2}$ for compost's shifting and packaging area. Anorganics and B3 area need $94.64 \mathrm{~m}^{2}$. Biogas fixed dome type reactor within $10 \mathrm{~m}^{3}$. Storehouse $80 \mathrm{~m}^{2}$. Parking lot $34.44 \mathrm{~m}^{2}$. Maintenance house $24 \mathrm{~m}^{2}$. The space needs for waste management in district scale is $4458,143 \mathrm{~m}^{2}$.
\end{abstract}

Keywords: Waste Management, Development, TPST 


\section{A. PENDAHULUAN}

Salah satu TPST yang sudah beroperasi di Kecamatan Pontianak Selatan adalah TPST Edelweiss.TPST Edelweiss menerima sampah Pasar Pagi sebanyak $\pm 560 \mathrm{Kg} /$ bulan. Pengolahan sampah yang terdapat di TPST Edelweis, yaitu dengan mengolah sampah organik menjadi pupuk kompos dan biogas. Pupuk kompos yang dapat dihasilkan dalam satu bulan $\pm 65 \mathrm{Kg} /$ hari, sedangkan biogas yang dapat dihasilkan dalam jangka waktu satu bulan $\pm 35 \mathrm{Kg} /$ hari (TPST Edelweiss, 2017). Luas bangunan TPST Edelweiss adalah $200 \mathrm{~m}^{2}$, akan dikembangkan menjadi skala kawasan khususnya di Kecamatan Pontianak Selatan. Luas TPST Edelweiss masih belum memenuhi persyaratan teknis sebagai acuan pengembangan TPST berdasarkan Peraturan Menteri Pekerjaan Umum No. 3 Tahun 2013, sehingga diperlukan pengembangan luas TPST. Rencana pengembangan ini merupakan salah satu upaya dalam meminimalisir persampahan di Kota Pontianak. Volume sampah yang akan masuk ke TPST Edelweiss akan bertambah jika mengalami pengembangan menjadi skala kawasan.

Berdasarkan latar belakang tersebut maka akan dilakukan kajian pengembangan TPST Edelweiss dari skala sampah pasar menjadi skala kawasan khususnya di Kecamatan Pontianak Selatan. Penelitian ini meliputi aspek teknik operasional, kapasitas TPST dan fasilitas TPST berdasarkan Peraturan Menteri Pekerjaan Umum Nomor 3 Tahun 2013 Tentang Penyelenggaraan Prasarana dan Sarana Persampahan dalam Penanganan Sampah Rumah Tangga dan Sampah Sejenis Sampah Rumah Tangga. Tujuan dari penelitian ini adalah, menganalisis timbulan sampah yang terdapat di Pasar Pagi dan kondisi eksisting pengelolaan sampah di TPST Edelweiss Kota Pontianak dari aspek teknik operasional. Menganalisis pengembangan pengelolaan sampah di TPST Edelweiss skala pasar menjadi skala kawasan. Manfaat ini adalah mendapatkan penerapan pengelolaan sampah di TPST Edelweis Kota Pontianak. Mendapatkan rencana pengembangan pengelolaan sampah di TPST Edelweis untuk Kecamatan Pontianak Selatan.

\section{B. METODE PENELITIAN}

\section{$>$ LOKASI KAJIAN}

Lokasi kajian berada di Kecamatan Pontianak Selatan dengan jumlah penduduk tahun 2018 sebanyak 96.021 jiwa. TPST Edelweiss berada di Kecamatan Pontianak Selatan. Batas administrasi Kecamatan Pontianak Selatan dapat dilihat sebagai berikut (BPS Kota Pontianak, 2017):

Utara : Kecamatan Pontianak Barat

Selatan : Kecamatan Sungai Raya Kabupaten Kubu Raya

Timur : Kecamatan Pontianak Timur

Barat : Kecamatan Sungai Kakap Kabupaten Kubu Raya

TPST Edelweiss terletak di $0^{\circ} 04^{\prime} 32,30^{\prime \prime}$ BT dan $109^{\circ} 18^{\prime} 50,52^{\prime \prime}$ LS, berada di Kecamatan Pontianak Selatan.

\section{$>$ PENGUMPULAN DATA}

Data primer yang akan diambil dalam penelitian ini adalah timbulan dan komposisi sampah pasar, diketahui jumlah unit Pasar Pagi sebanyak 117 unit. Jumlah sampel sampah dari Pasar Pagi dapat dihitung dengan menggunakan rumus purposive sampling. Sehingga banyaknya sampel sampah yang akan diambil di Pasar Pagi adalah sebanyak 43 sampel. Teknik pengambilan dan pengukuran sampel sampah mengacu pada SNI 193694-1994, Pengambilan sampel sampah dilakukan selama 8 (delapan) hari berturutturut dilakukan mulai dari hari kamis hingga hari kamis pada minggu selanjutnya. Cara pelaksanaan sampling timbulan dan komposisi sampah adalah dengan menimbang 
terlebih dahulu wadah (kotak pengukur/kompaktor) agar didapatkan berat wadah sebelum pengukuran berat sampah. Kemudian dimasukkan sampah yang telah dikumpulkan ke dalam wadah tersebut, wadah dihentakan sebanyak 3 kali dan setinggi $20 \mathrm{~cm}$. Kemudian timbang berat wadah dan volume berisi sampah tersebut dan catat hasilnya. Sampah tersebut kemudian akan dipilah berdasarkan komponen komposisi sampah (organik, anorganik dan B3). Kemudian ditimbang kembali dan dicatat berat dan volume komponen komposisi sampah.

Data sekunder yang digunakan dalam penelitian ini adalah data kependudukan Kecamatan Pontianak Selatan dan data timbulan sampah Kecamatan Pontianak Selatan unutk mengetahui banyaknya timbulan sampah yang terdapat dilokasi kajian. Data jumlah penduduk Kecamatan Pontianak Selatan didapat dari Badan Pusat Statistik Kota Pontianak. Data jumlah penduduk tersebut juga akan di proyeksikan dan dikali dengan data timbulan sampah Kecamatan Pontianak Selatan untuk mengetahui proyeksi timbulan sampah.

\section{ALAT DAN BAHAN}

Alat yang akan dipergunakan dalam sampling timbulan dan komposisi sampah berupa kantong plastik, wadah kompaktor $100 \mathrm{~cm} \times 50 \mathrm{~cm} \times 100 \mathrm{~cm}$ (500 L) dan $20 \mathrm{~cm} \times$ $20 \mathrm{~cm} \times 100 \mathrm{~cm} \mathrm{(40} \mathrm{L),} \mathrm{sarung} \mathrm{tangan} \mathrm{lateks,} \mathrm{timbangan} \mathrm{dan} \mathrm{masker.}$

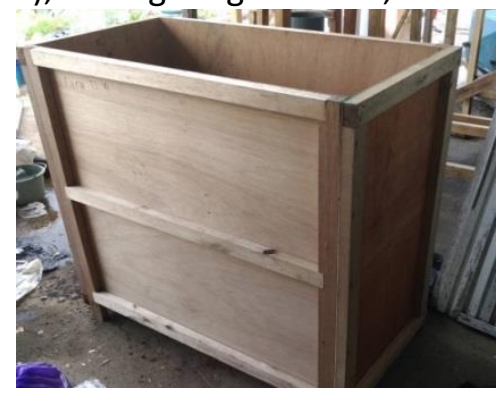

(a) Wadah $500 \mathrm{~L}$

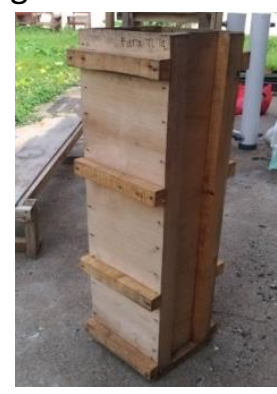

(b) Wadah $40 \mathrm{~L}$

Gambar 1 Dimensi Wadah Kompaktor

\section{HASIL DAN PEMBAHASAN}

\section{$>$ KONDISI EKSISTING}

Tempat Pengelolaan Sampah Terpadu (TPST) Edelweis didirikan pada tahun 2017. Luas bangunan dari TPST Edelweis ini adalah $200 \mathrm{~m}^{2}$. Sumber sampah yang dikelola berasal dari Pasar Pagi. Adapun sarana dan prasarana TPST Edelweiss dapat dilihat pada Tabel 1

Tabel 1 Sarana dan Prasarana TPST Edelweiss 2017

\begin{tabular}{|c|c|c|}
\hline No. & Area & Kriteria \\
\hline 1 & $\begin{array}{l}\text { Penumpukan dan pemilahan: } \\
\text { a. Tenaga kerja penumpukan } \\
\text { b. Tenaga kerja pemilahan } \\
\text { c. Alat pemilahan } \\
\text { d. Luas area }\end{array}$ & $\begin{array}{l}2 \text { orang } \\
1 \text { orang } \\
\text { Serokan } 1 \text { buah } \\
12 \mathrm{~m}^{2}\end{array}$ \\
\hline 2 & $\begin{array}{l}\text { Pencacahan dan Penimbangan: } \\
\text { a. Dimensi alat pencacah } \\
\text { b. Tenaga kerja } \\
\text { c. Luas area } \\
\text { d. Jenis wadah } \\
\text { e. Jumlah wadah } \\
\text { f. Timbangan }\end{array}$ & $\begin{array}{l}1,1 \mathrm{~m} \times 0,68 \mathrm{~m} \times 1,35 \mathrm{~m} \\
3 \text { orang } \\
12 \mathrm{~m}^{2} \\
\text { Keranjang anyam } \\
14 \text { keranjang } \\
1 \text { buah timbangan } 60 \mathrm{Kg}\end{array}$ \\
\hline
\end{tabular}




\begin{tabular}{|c|c|c|}
\hline No. & Area & Kriteria \\
\hline 3 & $\begin{array}{l}\text { Pengomposan: } \\
\text { a. Sistem pengomposan } \\
\text { b. Jumlah bak kompos } \\
\text { c. Dimensi bak kompos } \\
\text { d. Tenaga kerja }\end{array}$ & $\begin{array}{l}\text { Open bin } \\
21 \text { bak } \\
4 \mathrm{~m} \times 1 \mathrm{~m} \times 0,6 \mathrm{~m} \\
3 \text { orang }\end{array}$ \\
\hline 4 & $\begin{array}{l}\text { Pengayakan dan pengemasan kompos: } \\
\text { a. Jenis alat pengayakan } \\
\text { b. Jumlah alat } \\
\text { c. Tenaga kerja } \\
\text { d. Alat bantu pengemasan } \\
\text { e. Wadah kompos } \\
\text { f. Luas area }\end{array}$ & $\begin{array}{l}\text { Pengayak putar } \\
1 \text { unit } \\
2 \text { orang } \\
1 \text { sekop } \\
\text { Karung bekas layak pakai } \\
9 \mathrm{~m}^{2}\end{array}$ \\
\hline 5 & $\begin{array}{l}\text { Penyimpanan kompos: } \\
\text { a. Alat bantu } \\
\text { b. Timbangan } \\
\text { c. Luas area }\end{array}$ & $\begin{array}{l}\text { Gerobak sorong } 1 \text { buah } \\
1 \text { unit } \\
3 \mathrm{~m}^{2}\end{array}$ \\
\hline 6 & $\begin{array}{l}\text { Reaktor biogas : } \\
\text { a. Tipe digester } \\
\text { b. Ukuran digester } \\
\text { c. Dimensi reaktor } \\
\text { d. Jumlah reaktor }\end{array}$ & $\begin{array}{l}\text { Fixed dome } \\
\text { 10. } 000 \mathrm{~L} \\
\text { Diameter } 2 \mathrm{~m} \text {; tinggi } 3,3 \mathrm{~m} \\
1 \text { unit }\end{array}$ \\
\hline
\end{tabular}

Sampah yang masuk ke TPST Edelweiss tidak melewati penimbangan terlebih dahulu. Namun dilakukan proses penimbangan sampah yang masuk setelah proses pencacahan sehingga data berat sampah di TPST merupakan sampah organik. Sampah anorganik yang dihasilkan setelah proses pemilahan tidak ditimbang.

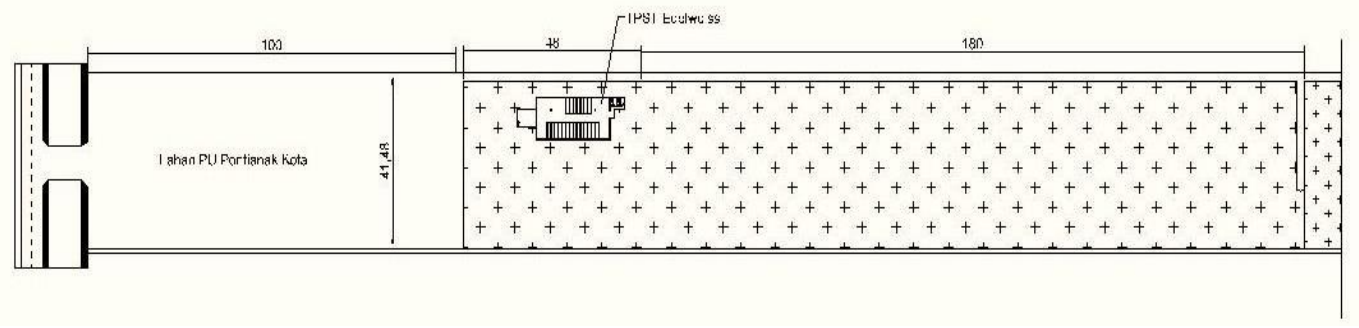

Gambar 2 TPST Edelweiss 2017

\section{$>$ TIMBULAN SAMPAH}

- Timbulan Sampah Pasar Pagi

Pengukuran timbulan sampah Pasar Pagi dilakukan selama 8 hari, mulai tanggal 22 Maret 2018 hingga 29 Maret 2018. Timbulan sampah didapatkan dari rerata berat sampah dan volume sampah per delapan hari, dibagi dengan jumlah unit sampel di Pasar pagi. Komposisi sampah di Pasar Pagi dikelompokkan menjadi dua jenis, yaitu sampah organik dan sampah anorganik.

Timbulan sampah yang dihasilkan dari sampah jenis organik adalah 4,561 $\mathrm{kg} / \mathrm{unit} / \mathrm{hari}$ atau $0,386 \mathrm{~m}^{3} / \mathrm{unit} / \mathrm{hari}$, dengan total timbulan yang dihasilkan adalah $533,659 \mathrm{~kg} /$ hari atau $45,174 \mathrm{~m}^{3} /$ hari. Sedangkan sampah jenis anorganik adalah 0,023 $\mathrm{kg} / \mathrm{unit} /$ hari atau $0,002 \mathrm{~m}^{3} / \mathrm{unit} /$ hari dengan total timbulan yang dihasilkan adalah 2,747 $\mathrm{kg} /$ hari atau $0,242 \mathrm{~m}^{3} /$ hari.

Sampah organik yang dihasilkan di Pasar Pagi berupa sayuran, tandan pisang, kulit telur dan sisa sisa makanan. Sedangkan sampah anorganik yang dihasilkan di Pasar Pagi berupa botol plastik, kantong plastik, karung plastik, potongan kardus, bungkus rokok 
dan tali rafia. Komposisi sampah organik yang dihasilkan Pasar Pagi adalah 99,49\%, sedangkan komposisi sampah anorganik yang dihasilkan adalah $0,51 \%$.

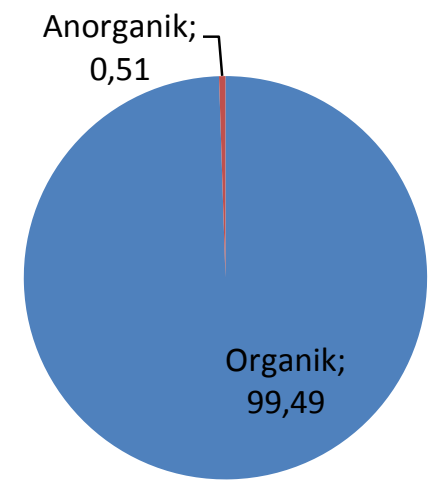

Gambar 3 Persentase Komposisi Sampah Pasar Pagi

Berdasarkan Gambar 3, dapat disimpulkan bahwa, Pasar Pagi menghasilkan sampah organik lebih besar dibandingkan dengan sampah anorganiknya. Hal ini dikarenakan pedagang yang berjualan di Pasar Pagi banyak menjual sayuran. Pedagang sayur tersebut membuang sisa potongan sayuran seperti akar-akar sayur langsung di bawah tempat jualan.

Proyeksi jumlah unit di Pasar Pagi di proyeksikan bertambah 2\% tiap tahun dengan perencanaan selama 5 tahun dari tahun 2018 - 2023. Pasar Pagi merupakan pasar tradisional di Kecamatan Pontianak Kota. Pada tahun 2023 jumlah unit di Pasar Pagi sebanyak 129 dengan total sampah organiknya 589,203 kg/hari dan 49,876 $\mathrm{m}^{3} / \mathrm{hari}$ sedangkan total sampah anorganik sebanyak $3,033 \mathrm{~kg} / \mathrm{hari}$ dan $0,268 \mathrm{~m}^{3} / \mathrm{hari}$. Timbulan sampah yang akan masuk ke TPST Edelweiss sebanyak $50 \%$ dari total timbulan sampah. Hal ini dikarenakan pelayanan sampah di TPST Edelweiss 2017 menerima sampah Pasar Pagi sebanyak 50\% dari total sampah. Tahun 2023 dengan total sampah yang masuk adalah $296,118 \mathrm{~kg} /$ hari atau $25,072 \mathrm{~m}^{3} /$ hari.

- Timbulan Sampah Pontianak Selatan

Timbulan sampah di Kecamatan Pontianak Selatan mencapai 0,2 kg/orang/hari atau sebesar $0,001769 \mathrm{~m}^{3}$ /orang/hari (Fitria, 2016). Berat dan volume sampah pada tahun 2023 adalah 21107,62 kg/hari dan 186,70 $\mathrm{m}^{3} /$ hari. Pelayanan sampah akan direncanakan meningkat $2 \%$ tiap tahun. Tahun 2018 pelayanan akan dilakukan sebesar 29\% dan pada tahun 2023 pelayanan sebesar 39\%, sehingga berat dan volume sampah tahun 2023 adalah 8231,972 kg/hari atau 72,812 $\mathrm{m}^{3} /$ hari. Sampah yang akan masuk ke TPST Edelweiss adalah total sampah pasar pagi 50\% dan sampah Pontianak Selatan 39\%, sehingga pada tahun 2023 sampah yang akan masuk ke TPST Edelweiss adalah 8528,090 $\mathrm{kg} / \mathrm{hari}$ atau $97,884 \mathrm{~m}^{3} /$ hari.

\section{$>$ PENGUMPULAN DAN PENGANGKUTAN}

Pengumpulan sampah di Pasar Pagi dengan volume sampah 25,072 $\mathrm{m}^{3}$ membutuhkan kontainer sebanyak 2 kontainer dengan kapasitas $6 \mathrm{~m}^{3}$. Pengangkutan menggunakan armroll truck sebanyak 2 truk dengan ritasi pengangkutan adalah 2 ritasi. Pengumpulan sampah Kecamatan Pontianak Selatan dengan volume sampah $72,812 \mathrm{~m}^{3}$ membutuhkan kontainer sebanyak 3 kontainer dengan kapasitas $6 \mathrm{~m}^{3}$. Pengangkutan menggunakan armroll truck sebanyak 3 truk dengan ritasi pengangkutan adalah 4 ritasi.

Pengangkutan sampah akan dilakukan dengan mengangkut sampah yang ada di Kecamatan Pontianak Selatan terlebih dahulu, kemudian mengangkut sampah di Pasar 
Pagi. Hal ini dikarenakan aktivitas yang terdapat di Pasar Pagi berakhir pada pukul 11.00 WIB. Jumlah truk yang dibutuhkan untuk mengangkut sampah Pasar Pagi dan Kecamatan Pontianak Selatan ke TPST Edelweiss adalah sebanyak 3 truk. Sistem pengangkutan sampah yang akan direncanakan adalah menggunakan pengangkutan sistem HCS tipe 2. Armroll truk dari TPST menuju kontainer sampah Kecamatan Pontianak Selatan, kemudian kontainer 1 diangkut ke TPA untuk di bongkar. Kontainer kosong diletakkan di lokasi kontainer 2 dan kontainer 2 yang sudah terisi kemudian diangkut ke TPA, demikian seterusnya hingga rit terakhir. Pada akhir operasi, kontainer kosong dari Pasar Pagi diangkut menuju lokasi kontainer sampah Kecamatan Pontianak Selatan. Kemudian truk kembali ke TPST Edelweiss tanpa membawa kontainer.

\section{$>$ PENGELOLAAN}

Waktu operasional TPST Edelweiss adalah 9 jam kerja dari jam $07.00-16.00$ WIB. Ritasi Pengangkutan sampah untuk sampah pasar adalah 2 ritasi dan sampah penduduk di Kecamatan Pontianak Selatan sebanyak 3 ritasi. Sampah yang akan diolah di TPST Edelweiss direncanakan masuk setiap hari dengan total sampah sebanyak $97,884 \mathrm{~m}^{3}$. Berikut hasil perencanaan pengembangan TPST Edelweiss:

Tabel 2 Perencanaan Luas TPST Edelweiss

\begin{tabular}{clc}
\hline No. & \multicolumn{1}{c}{ Area } & Luas Area $\left.\mathbf{( m}^{\mathbf{2}}\right)$ \\
\hline 1 & Penumpukan & 100 \\
\hline 2 & Pemilahan & 157,44 \\
\hline 3 & Pencacahan & 36,8 \\
\hline 4 & Pengomposan & 3421,83 \\
\hline 5 & Pengayakan dan pengemasan kompos & 16,5 \\
\hline 6 & Area anorganik dan B3 & 94,64 \\
\hline 7 & Gudang anorganik & 339,774 \\
\hline 8 & Gudang B3 & 86,719 \\
\hline 9 & Gudang penyimpangan kompos & 80 \\
\hline 10 & Lahan parkir armroll truck & 34,44 \\
\hline 11 & Lahan parkir pegawai & 66 \\
\hline 12 & Rumah jaga & 24 \\
\hline & & Total
\end{tabular}

Total luas lahan pengembangan TPST Edelweiss adalah 4458,143 $\mathrm{m}^{2}$. Sehingga dapat disimpulkan bahwa, bangunan TPST Edelweiss tahun 2017 tidak mampu mengelola sampah jika ditambah dengan sampah skala kawasan. Namun, jika mengalami renovasi dan penambahan beberapa alat pemilahan, pencacahan dan pengayakan serta penambahan luas lahan sesuai perencanaan, TPST Edelweiss dapat mengelola sampah skala kawasan. Sarana dan prasana yang direncanakan pada pengembangan TPST Edelweiss untuk skala kawasan sebagai berikut:

Tabel 3 Sarana dan Prasarana TPST Edelweiss

\begin{tabular}{|c|c|c|}
\hline No. & Area & Kriteria \\
\hline \multirow{4}{*}{1} & Penumpukan: & \\
\hline & a. Volume sampah & $97,884 \mathrm{~m}^{3}$ \\
\hline & b. Jumlah bak & 1 bak \\
\hline & c. Dimensi bak & $10 \mathrm{~m} \times 10 \mathrm{~m} \times 1 \mathrm{~m}$ \\
\hline \multirow{5}{*}{2} & Pemilahan: & \\
\hline & a. Jumlah conveyor belt & 1 alat \\
\hline & b. Panjang conveyor belt & $12,5 \mathrm{~m}$ \\
\hline & c. Tinggi conveyor belt & $80 \mathrm{~cm}$ \\
\hline & d. Lebar conveyor belt & $60 \mathrm{~cm}$ \\
\hline
\end{tabular}




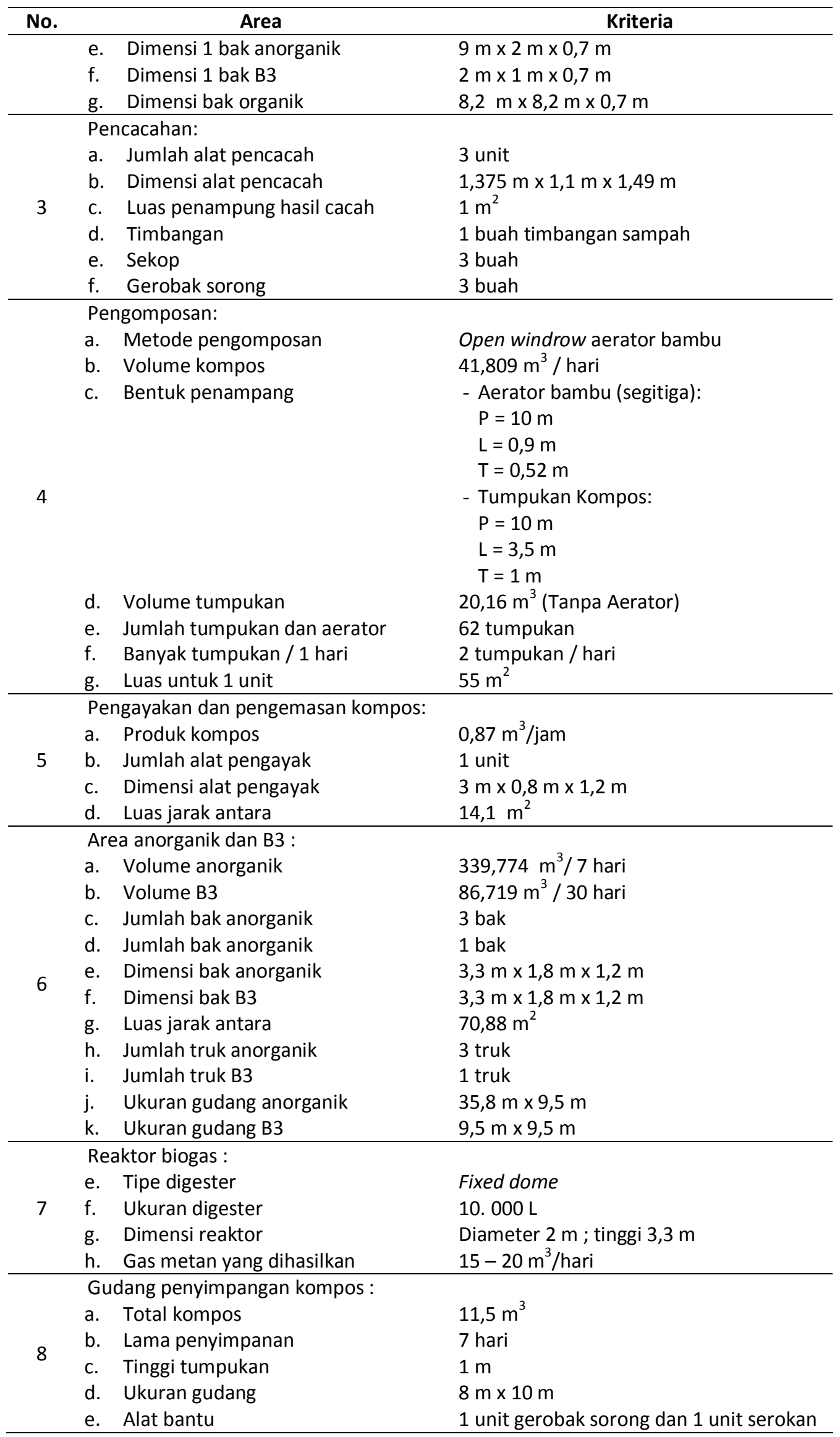




\begin{tabular}{cll}
\hline No. & \multicolumn{1}{c}{ Area } & Kriteria \\
\hline \multirow{2}{9}{9} & $\begin{array}{l}\text { Lahan parkir armroll truck: } \\
\text { a. Jumlah truk } \\
\text { b. Dimensi armroll truck }\end{array}$ & 3 truk \\
\hline 10 & $\begin{array}{l}\text { Rumah jaga : } \\
\text { a. Ukuran rumah jaga }\end{array}$ & $5,7 \mathrm{~m} \times 2 \mathrm{~m} \times 2,46 \mathrm{~m}$ \\
\hline
\end{tabular}

TPST Edelweiss membutuhkan bak penumpukan sampah di area penumpukan, alat conveyor belt untuk membantu pekerja dalam proses pemilahan sampah, penambahan alat pencacah sampah menjadi 3 unit, metode pengomposan menggunakan metode open windrow dengan sistem aerator bambu. Penambahan area anorganik dan B3 dengan merencanakan gudang penyimpanan serta jumlah kontainer yang dibutuhkan, penambahan gudang penyimpanan kompos serta terdapat rumah jaga.

Sampah anorganik dan B3 yang telah melalui proses pemilahan, kemudian akan dipindahkan ke dalam kontainer dan diangkut menuju TPA. Volume kontainer untuk sampah anorganik dan B3 menggunakan kontainer $6 \mathrm{~m}^{3}$ dengan dimensi 3,3 $\mathrm{m} \mathrm{x} \mathrm{1,8} \mathrm{m} \times$ 1,2 m. Menurut PP 101 tahun 2014, lama penyimpanan sampah B3 diatas $50 \mathrm{Kg}$ paling lama adalah 90 hari. Penyimpanan sampah B3 yang akan direncanakan adalah selama 30 hari, sehingga volume sampah B3 setelah proses pemilahan akan dikali 30 hari menjadi $86,719 \mathrm{~m}^{3}$. Lama penyimpanan sampah anroganik yang akan direncanakan adalah selama 7 hari. Setiap 7 hari sekali sampah anorganik akan diangkut ke TPA, sehingga volume sampah anorganik setelah proses pemilahan akan dikali 7 hari menjadi 339,774 $\mathrm{m}^{3}$.

Pengangkutan sampah anorganik dan B3 akan dilakukan dengan sistem HCS tipe 3. Kendaraan dari pool membawa kontainer kosong menuju TPST untuk mengambil kontainer isi kemudian langsung menuju ke TPA, demikian seterusnya hingga ritasi terakhir (PerMen PU No. 3, 2013). Sistem pengangkutan sampah yang akan direncanakan adalah menggunakan pengangkutan sistem HCS tipe 3. Armroll truk dari TPA menuju TPST dengan membawa kontainer kosong, kemudian kontainer kosong di tukar dengan kontainer isi. Kontainer 1 yang telah di isi diangkut ke TPA untuk di bongkar. Kontainer kosong diletakkan di lokasi kontainer 2 dan kontainer 2 yang sudah terisi kemudian diangkut ke TPA, demikian seterusnya hingga rit terakhir. Pada akhir operasi, truk kembali ke TPA dengan membawa kontainer kosong.

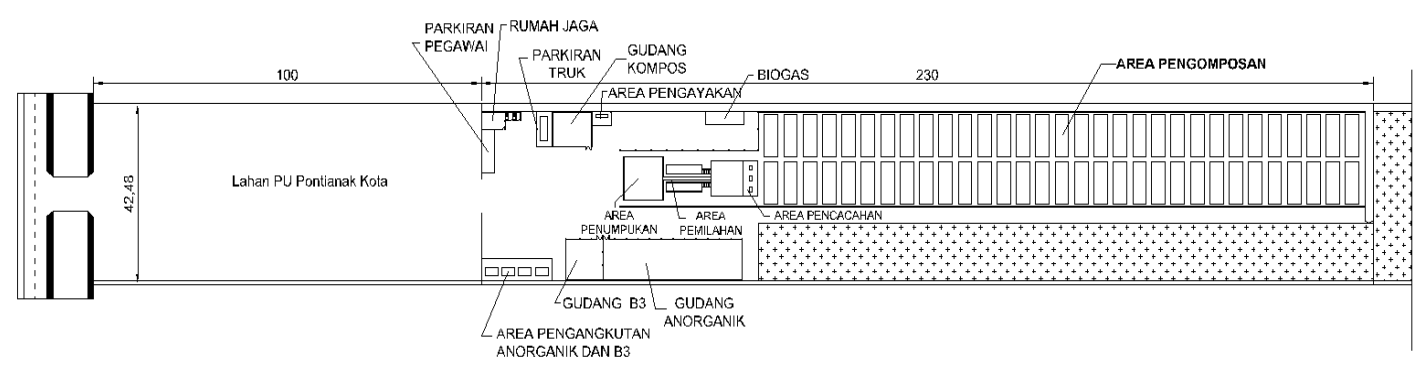

Gambar 4 Perencanaan TPST Edelweiss 2023

Kemudian kebutuhan tenaga kerja yang dibutuhkan TPST Edelweiss dapat dilihat pada Tabel 4: 
Tabel 4 Kebutuhan Tenaga Kerja TPST Edelweiss

\begin{tabular}{clc}
\hline No. & \multicolumn{1}{c}{ Area } & $\begin{array}{c}\text { Tenaga Kerja } \\
\text { (Orang) }\end{array}$ \\
\hline 1 & Penumpukan & 3 \\
\hline 2 & Pemilahan & 20 \\
\hline 3 & Pencacahan & 3 \\
\hline 4 & Pengomposan & 7 \\
\hline 5 & Pengayakan dan pengemasan kompos & 3 \\
\hline 6 & Area anorganik dan B3 & - \\
\hline 7 & Reaktor biogas & - \\
\hline 8 & Gudang penyimpangan kompos & - \\
\hline 9 & Lahan parkir armroll truck & - \\
\hline 10 & Rumah jaga & 36 \\
\hline & & Total
\end{tabular}

Total tenaga kerja yang dibutuhkan di TPST Edelweiss adalah 36 orang. Namun, tenaga kerja tersebut dapat di minimalkan menjadi 23 orang. Hal ini dikarenakan pengerjaan di aera penumpukan dan pemilahan terlebih dahulu, kemudian 3 orang pegawai melakukan pekerjaan pencacahan. Setelah melakukan pencacahan, 7 orang pegawai melakukan penumpukan kompos dan 3 orang pegawai melakukan kegiatan pengayakan.

\section{PENUTUP}

\section{KESIMPULAN}

Adapun kesimpulan yang dapat diberikan dari penelitian ini adalah:

- Total timbulan sampah yang terdapat di Pasar Pagi adalah 533,659 kg/hari atau $45,174 \mathrm{~m}^{3} /$ hari untuk sampah organik dan $2,747 \mathrm{~kg} /$ hari atau $0,242 \mathrm{~m}^{3} /$ hari untuk sampah anorganik. Kondisi eksisting TPST Edelweiss mempunyai luas bangunan $200 \mathrm{~m}^{2}$. TPST Edelweiss memiliki area penimbunan dan pemilahan dengan luas 12 $\mathrm{m}^{2}$ memiliki 1 unit timbangan dan 1 unit serokan, area pencacahan dengan luas 12 $\mathrm{m}^{2}$ memiliki 1 unit alat pencacah, area pengomposan dengan luas 1 bak kompos adalah $4 \mathrm{~m}^{2}$ dan memiliki 21 bak pengomposan, area pengayakan dengan luas 9 $\mathrm{m}^{2}$ memiliki 1 unit alat pengayak, area penyimpanan kompos memiliki luas $12 \mathrm{~m}^{2}$ dan reaktor biogas dengan kapasitas $10.000 \mathrm{~L}$.

- Pengembangan TPST memerlukan luas lahan 4458,143 $\mathrm{m}^{2}$. Luas masing masing area yaitu, area penumpukan $100 \mathrm{~m}^{2}$, area pemilahan $157,44 \mathrm{~m}^{2}$, area pencacahan $36,8 \mathrm{~m}^{2}$, area pengomposan dengan metode pengomposan open windrow composting $3421,83 \mathrm{~m}^{2}$, area pengayakan dan pengemasan kompos 16,5 $\mathrm{m}^{2}$, gudang penyimpanan kompos $80 \mathrm{~m}^{2}$, rumah jaga $24 \mathrm{~m}^{2}$, lahan parkir truk $34,44 \mathrm{~m}^{2}$ dan lahan parkir pegawai adalah $66 \mathrm{~m}^{2}$, luas area pewadahan anorganik dan B3 adalah 94,64 $\mathrm{m}^{2}$, gudang anorganik adalah $339,774 \mathrm{~m}^{2}$ dan gudang B3 adalah $86,719 \mathrm{~m}^{2}$.

SARAN

Adapun saran dari penelitian ini, diperlukan analisis pada aspek pembiayaan, kelembagaan, peraturan dan peran serta masyarakat pada pengembangan TPST Edelweiss skala kawasan. 


\section{UCAPAN TERIMA KASIH}

Puji dan syukur saya panjatkan kehadirat Allah SWT karena atas berkat dan rahmat serta hidayah-Nya saya dapat menyelesaikan tugas akhir saya. Terima kasih kepada Ibu Laili Fitria, S.T., M.T. dan Ibu Ulli Kadaria, S.T., M.T. selaku dosen pembimbing serta Ibu Yulisa Fitrianingsih, S.T., M.T dan Bapak Hendri Sutrisno, S.T., M.T selaku dosen penguji. Terima kasih juga saya ucapkan kepada keluarga dan kawan kawan Teknik Lingkungan 2014 yang telah membantu saya dalam menyelesaikan tugas akhir. Semoga penelitian ini dapat bermanfaat bagi semua pihak.

\section{DAFTAR PUSTAKA}

Badan Standarisasi Nasional, 1994. Metode Pengambilan dan Pengukuran Contoh Timbulan dan Komposisi Sampah Perkotaan SNI 19-3964-1994. Jakarta

BPS Kota Pontianak. 2017. Kecamatan Pontianak Selatan dalam Angka. Pontianak: Badan Pusat Statistik.

Fitria, Laili. 2016. Analisis Dampak Pertumbuhan Penduduk Kota Pontianak Terhadap Kapasitas Lahan dan Masa Pakai Tempat Pemrosesan Akhir (TPA) Batu Layang Kota Pontianak. Pontianak: Universitas Tanjungpura

Peraturan Menteri Pekerjaan Umum RI Nomor 3 Tahun 2013 Tentang Penyelenggaraan Prasarana dan Sarana Persampahan Dalam Penanganan Sampah Rumah Tangga dan Sampah Sejenis Sampah Rumah Tangga

TPST Edelweiss. 2017. Buku Data Harian Sampah TPST Edelweiss. Pontianak 